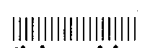

特 集 確率ファジィ解析とその周辺

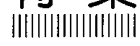

\title{
確率ファジイ解析 $^{\dagger}$ \\ 一「確率ファジ獬析と光の周辺」特集にあたってー
}

\section{小倉 幸雄*}

\section{1. はじめに}

1997 年 10 月 9 日 (木) -10 月 11 日 (土), 佐賀大 学理工学部で研究集会『ファジィ解析とその周辺』 が開催された。文部省科学研究費補助金基盤研究 (B) (2)の援助によるものである.もともと数学の 世界では，科学研究費で研究集会を開き，基本的 結果の紹介と新しい結果についての講演と討論を 行なうことにより，その分野の現状把握と，今後 の発展の方向を探ることは珍しいことではなく， これは有形, 無形に当該研究に寄与寸るところが 大きい，付録に講演者と講演題目の一覧を揭げて おいたので，興味のある方は参照して頂きたい.

本特集は, そのときの講演の中から, 特に研究 集会のテーマである確率ファジィ解析に直結して いるものを選び，講演者に執筆を依頼したもので ある、数学者の文章は難解になり易く, 読み難い というのが定評であるが, 各執筆者ともその点に は注意して頂いなので，基礎的なところから分り 易く解き起してくれているようである。それらへ のより簡易な導入を, というのが本稿の目的であ るが,これは屋上屋ならぬ『床下床』かも知れな い.せ女て，導入により却ってわけが分らなくな ったななということのないように気を付けなけ ればなるまい。

$\uparrow$ Stochastic Fuzzy Analysis

本研究は，文部省科学研究費補助金基盤研究 (B) (2) (課題番 号 09440085)からの援助によるものである。

Yukio OGURA

* 佐賀大学理工学部数理科学科

Department of Mathematics, Faculty of Science and Engineering, Saga University
最後に，本特集は前出の研究集会に出席された， 水本雅晴本紙編集委員 (現 日本ファジィ学会会 長)の勧めによるものでる.この場を借りて同編集 委員に謝意を表するものである。

\section{2. 確率ファジィ解析とは何か}

この言葉は新語であり，私の創作である。少な くとも私自身は何処からか引っぱって来たわけで はないので，そう思っている。しかし，この言葉 を研究集会の題名にしたりして，平然と使ってい るが，その意味について質問されたことがない。 近年の情報洪水の中で，様々な新語が出ては消え しているので，別に気にもされなかったとも言え るが，もうひとつの解釈としては，『意自ずから生 ず』でネーミングが自然で分り易かったのかも知 れないと，や、我田引水的な解粉もある。だが， 寧ろ新しい分野が現われるときには何時もそうな のだが，例えば「100人の情報科学研究者がいる と, 100 種類の情報科学が存在する」と言れるよう に，夫々に人が夫々のイメージで自分流にこの言 葉を捉えておられると考えた方が妥当だろう。そ れはそれで結構なことなので，これを第一の定義 (広義の定義)として抗こう。即ち,

広義の定義『確率ファジイ解析』とは, 夫々の 人が持つ『確率ファジィ解析』の集合であって, その意味は時間の経過とともに確定して行くもの である。

ということになる. 
だが,これでは少し無責任で「それでは，おま えの『確率ファジィ解析』は何か」と問われかね ない.そこで, 私なりの広辞苑的な定義(狭義の定 義)を与えてみると

狭義の定義 『確率ファジィ解析」とは, ファジ イに現われる確率的な現象を解析する学問である。

となる。これは単語を適当に結びつけただけでは ないか，と思われるかも知れないが，いくつかの 可能性を捨象している。ひとつは，例えば『確率 解析」と言ったときには，確率的な現象を解析す るだけでなく, 解析学の奥に隠れている確率的な 原理を見つけ出し，その原理を用いて解析学を行 なうことが，主要な分野として含まれているが, 上の定義からこのことに対応することを捜すのは 困難である。また，測度論も確率解析の一分野と 言えるが，その拡張であるファジィ測度論も上の 定義に入れ難い。それで，第 3 の定義ということ になるが,

第 3 の定義 『確率ファジィ解析』とは, ファジ イに関連する確㳯解析，またはその拡張である。

ということにしておこう。こうすると, 大分多く の人に受け入れられ易くなるが，や〉無責任とも いえる『広義の定義』との差もあまり無くなる.

そこでこの節の結論だが, 多分正しいのは『定 義は第 3 の定義』だが，個人的には当面『狭義の 定義』を支持したい.そして，時代とともにこの 分野が発展して行って, 『第 3 の定義』が真の意味 を持つようになることを期待したい。

\section{3. 確率とファジィの結びつき}

ファジィの概念が世に出たとき，一見それが確 率と似ている為に「確率論と何処が違うのか」と いう疑問が出され，その違いを強調するあまりに， 確率論の研究者とファジィの研究者の距離が離れ て行った，という不幸な経緯がある。幸いにして， 私自身は当時はファジィについて何も知らなかっ たので，そのような確執から免れたので，双方の
学問について何の拘りも持たずに済んでいる. その私なりの解勫では,「あいまいさをメンバシ ップ関数で表すのがファジィで, 確率で表わすの が確率論である」と考える. 勿論, 多くの場合メ ンバシップ関数は規格化可能で, そのときは確率 密度関数と見なせなくはない.しかし, 規格化出 来ない場合もあるわけだし，その場合例えば情報 量についての Rényi 流の解釈をしょうと思うと 一工夫必要である ([6]参照)，更に言えば，たとえ 規格化出来て, 確率密度関数で表わされたとして も，そのことを用いた確率解析がなければその甲 斐がないし，接近法が違うのに無理にそうすると 本来に意味を失ないかねないという危惧さえある。 ただし，双方の違いを認めた上で，互いの共通点 にも目を向け，深いところで繫がっていることを 明かにし，互いの長所を取り入れるようにしなけ ればならないことは，どの分野について言えるこ とである。

もう一つのファジィの手法は, ファジィ测度で ある、ファジィ関係等は，基底の空間を複雑にす ればメンバシップ関数で表わされないことはない が，一般のファジィ測度はそうはいきそうにない。 これは確率測度の拡張であり, 容量の拡張であり, その意味では測度論に近い.

上での話は，確率とファジィを対立的または協 調的に捉える立場で，この二つは同じ土俵に上に 乗っている。しかし，これを立体的に捉える立場 はないだろうか？

例を一つ挙げよう。 $\omega_{1}, \omega_{2}, \cdots, \omega_{n}$ の八の人

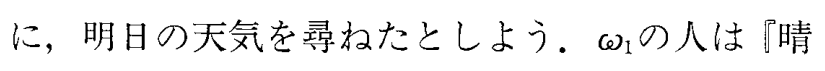
れ』と言い, $\omega_{2}$ のはは『曇』というだろう。しか し， $\omega_{3}$ の人は倩だろが, 曇かも知れない』とい

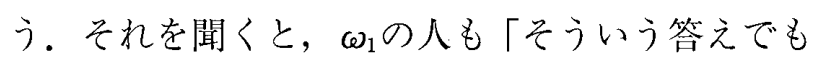
良いのなら，『大体晴』という回答に変更する」と いうかも知れない。. すると雨になるかも知れない』と回答を変えるか も知れない．結局，人間の予想というのはあいま いで，ファジィな形でしか答えられない。という より，その方が自分の気持に正直で自然であると いうことである。こう考えると，これらの人の回 
答は，晴の度合を横軸に取った，メンバシップ関 数で表わすのが良いだろう。それは，例えば四 1 の ようになる。

なかには，もっとちゃんとした確信を持ってい る人がいて, 絶対に晴だとか, 絶対に雨だとかい う人もいるかも知れないが，そのときは何時もす るように，クリスプ集合や，一点に集中した関数 をメンバシップ関数ととってくればよい。こうし て得られる $\left\{X\left(\omega_{k}\right)\right\}_{k=1,2, \cdots, n}$ がファジィ值確率変 数またはランダムファジィ集合である。勿論, 確 率変数というからには, 確率空間 $(\Omega, F, P)$ を準備 しておかなければならないが，今の場合，それら は暗に自然なものが与えられている。即ち， $\Omega=$ $\left\{\omega_{1}, \omega_{2}, \cdots, \omega_{n}\right\} て ゙, F$ は $\Omega$ 部分集合全体, $P$ は

$$
P(A)=\frac{1}{n} \# A
$$

(\# $A$ は集合 $A$ の元の総数を表す)でちえられる ものである。実は， $P$ は別に上式でなくてもよ く，色々な与え方があるが，ここでは全ての人の 予想に対し同等な重み与えることにした。

この例では，直観的に確率変数を定義して後で それに相応しい確率空間を定義したが，先ず適当 な確率空間を与え，その上のファジィ值確率変数 を与えるのが普通である。その際に㛜密にやろう とすると, 可測性とかのや>繁雑な議論を必要と する。ここではそれらには触れないことにするが， 本特集で日合文雄氏が初歩的なところから分り易 く解説しているので御覧頂きたい.

なおこの例では，人間の予想する結論のあいま いさを，メンバシップ関数で表すことによってフ アジィ值確率変数が得たが，対象になるもの固有 の性質によって，ファジィ值確率変数が現れる例 も沢山ある。天気予報に関連したものでは，気压 配置とか雲の分布などがそれに当る，前者では， 確率変数 $X(\omega)$ の值は地表上の点から気圧の值 をとる関数である。特に台風などは，狭い範囲の データですむので恰好な例となるだろう。後者で は， $X(\omega)$ は地表の点から雲の密度の值を取る関 数である，厭，寧ろ 3 次元的に考えて，地上何キ

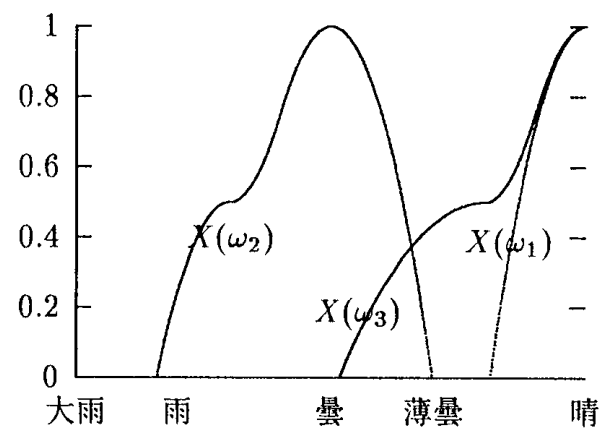

図1 天気の予想のファジィ值確率変数

ロか以下の空間の点から，雲の密度への関数とし た方が適切だろう。

これらの例に現れる確率変数をファジィ值と解 釈することには，異論もあるかも知れない。しか し, 数学的にメンバシップ関数の值を取る確率変 数を捉えるには，一般の関数值確率变数を解明す る手段を開発しなければならず，そこまで広げる と，そのイメージを与える良い例になっていると 言えよう。何れにせよ，このように考えると，確 率とファジィは対立するものではなく，自然と結 びつくのである。それに，これは確率変数の拡張 という形での雨者の結びつきであるが，まだまだ 他の結びつきも沢山あるかも知れない。

\section{4. ファジィ值確率变数と集合值確率変数}

ファジィ值確率変数 $X(\omega)$ を調べるのには，い くつかの方法がある。例えば，メンバシップ関数 を正規三角形関数 (1の值をとる三角形) に限定す ると, 図 2 のように, $X(\omega)$ は 3 つ確率变数 $l(\omega), m(\omega), r(\omega)$ だけで決まるので, これらの 性質を調べて $X(\omega)$ に接近するという方法があ る.

また，メンバシップ関数を 1 次元凸関数に限定 して, 四 3 のように, $X(\omega)$ をそれを決める右側関 数 $R(\omega)$ と左側関数 $L(\omega)$ のふたつの関数に帰着 させて，これを調べる方法もあるだろう。

これらの方法は, その特殊性を生かしたもので, 大变有用な方法である。しかし，数学者の習性と 


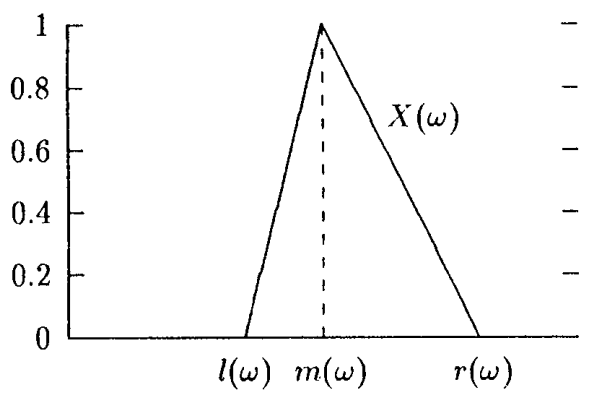

図2 三角形ファジィ值確率変数

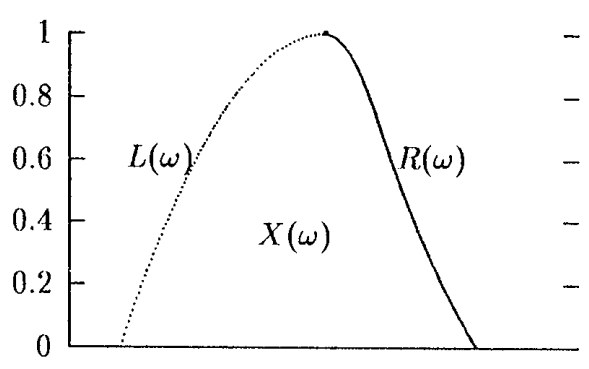

図3凸型ファジィ確率変数

してもう少し一般の形で定義しておきたいという 気がおこる。その要求をみたすのが，最も標準的 な方法, 即ちレベル集合に切ってそれを積み上げ る方法である。

※上のメンバシップ関数をもつファジィ值確率 変数 $X(\omega)$ と $\alpha \in[0,1]$ に対して

$$
X_{\alpha}(\omega)=\{x \in \mathfrak{X}: X(\omega) \geq \alpha\}
$$

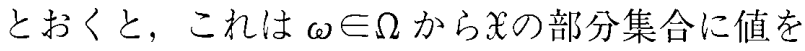
とる写像と考えられる。可測性の議論を無視する と, $X_{\alpha}(\omega)$ は集合值確率変数またはランダム集合 とよばれるものとなる。そこで，「関係式

$$
X(\omega)(x)=\sup \left\{\alpha: x \in X_{\alpha}(\omega)\right\}
$$

で定まるメンバシップ関数をもつファジィ值確率 変数が元の $X(\omega)$ に一致する」，ということを利 用して $\left\{X_{\alpha}(\omega): \alpha \in[0,1]\right\} の$ 性質を調べること により， $X(\omega)$ の性質を得ようという方法である. この極く当たり前の方法が割と有用である。と いうのは，ランダム集合の研究は結構前から行わ れていて，それなりの蓄積があるからである。実 際, ランダム集合の研究は, 私の知っている範囲
でも，古くは1944 年の Robbins の仕事[21]があ る.その後, Choquet[2]は容量からランダム集合 を構成することを試みているが，この仕事は別の 接近を行なったD. G. Kendall[10]に注目される ことになるのだが，そこら辺のからみは，本特集 の神田 護氏の記事に詳しく紹介されている。因み に，氏の記事はランダム集合の構成を初学者向け に解説していて有用であることは勿論だが，数学 物語の読物としても面白い。

尚，神田氏の解説のランダム集合の定義は，一 見上の定義と異るように見えるが，本質的には同 じものである。この違いは, 多分 Choquet の問題 意識が，その序文でも触れているように，容量そ のものにあったことからきているように見える。 また，ファジィ值確率変数からレベル集合を作る とき，

$$
X_{\alpha+}(\omega)=\{x \in \mathfrak{X}: X(\omega)>\alpha\}
$$

と真の不等号にするか, 或いは, $X_{\alpha}(\omega)$ と $X_{\alpha+}$ (心)との間の集合を取るかという議論があるが, これは定式化するときに，どのバージョンを取る かだけの問題で，あまり本質的な問題ではないと 思う。

\section{5. 現状と展望}

以下は，私見にもとづく『現状と展望』で，全 てを網羅しているものではない。特に，ファジィ 測度とファジィ積分に関することは，完全に久落 していることを断っておく。

ファジィ值確率変数の研究の一つの捉え方とし て, 普通の実数值確率変数, ベクトル值確率変数, 集合值確率変数, ファジィ值確率変数, と一般化 の流れとみる見方がある．勿論，この見方は一面 的で, 実際の研究は研究者のもつ與味, 洞察力, 見識，それに外部との交流等によって行なわれる もので，単なる一般化というのは，あまり良い見 方ではない。しかし，例えばある具体的な問題を 与えられたとき，それがどのような形で解けるか いうことは，その時代の水準に依るところが大き 
く，その意味で時代の到達点というのも重要な要 素で，その意味で, 敢えてこの立場から見てみよ う。時代から言うと，集合值確率変数が現われた のは，前出のように 1950 年前後で，ファジィ值確 率変数の研究は 1980 年頃である。後者の発展に は，Ralescu と Puri の寄与が大きく，最近ではス ペインの Gil とそのグループが活発である.

5.1 構成と可測性 ランダム集合研究は，4節で 述べたように, 私の知識の範囲では 1950 年前後に 始められたと思うが，先ず問題となるのは構成だ ろう。これについては，前出の神田氏の記事が詳 しいので，それに讓ることする。([15]も参照). 次が可測性だが，上で触れた日合氏の記事が，フ アジィ值確率変数の場合も含めて充分の解説して くれているので，その記事とそこにある文献を参 照されたい。そこにもあるように，可測性は可測 選択と直接的に関係しており，この可測選択は， 凸解析の方から来た支持関数とともに，ランダム 集合の性質を導くための重要な手段になっている。 尚, 集合值関数の可測性については, 最近出た [20] でも最後を 1 章を割いているので，参照されたい。 余談だが，この本の他の章はランダムでない集合 に関することだが，これらは必ずしもランダムで ないファジィ解析の研究に役立ちそうである。

\section{2 大数の法則}

大数の法則は，確率論における最も基本的な問 題で，その発祥はJacob Bernoulli の『推論術』 （1713）に遡る。その後, de Moivre と Quetelet は，確率を独立な試行の相対頻度の極限と考える ようになるようになるのだが，これをべクトル值 確率変数に拡張するのは容易である，集合值確率 変数の場合，その取る值がコンパクト集合のとき は, Shapley-Fokmanの不等式を使って凸集合値 の場合に帰着させ，これをある Banach 空間へ埋 込む，という方法を取る。しかし，これは独立 同分布の場合で，この条件を外すと事は複雑であ る。この辺りの事情については, 本特集の井上 洋 氏の記事が，初歩的なところから詳しく解説して あるので参照されたい。コンパクト集合値という
条件を外すと, 位相の問題等も出て来て話は更に 複雑になるが，[8]が良く纏っている．また，大数 の法則はファジィ值確率変数についてもいくつか の結果があるが，これについても井上氏の記事に 譲ることにする。

\section{3 牽引域定理}

大数の法則の一般化のひとつの方向は, 分布に ついての仮定を緩めることである，即ち，対応す る確率変数を可積分としないで，その代りに分布 の遠方での退化の速さの条件を与えて，独立確率 変数の和をその退化の速さを決める量に関係した 適当なパラメータで規格化し，その極限を得よう とするものある。所謂率引域 (domain of attraction）理論の集合值版であるが，詳しくは[4]にあ るので，興味のある方は，それとそこにある文献 を参照されたい。なお，上の議論では集合の『和』 は全て Minkowski 和，即ち

$$
A+B=\{a+b: a \in A, \quad b \in B\}
$$

(場合によってはこの閉包をとることもある)を用 いているが，[16]では代りに集合和を用いて同様 な議論を展開している。べクトル值との対応で言 えば, Minkowski 和が, 通常の和に対応している のに対し，集合和の方は最大值を取ることに対応 している，例も豊富なので，この方向の研究は今 後も期待が持てそうである。

\section{4 中心極限定理}

大数の法則, 澈引定理と続くと, 次は中心極限 定理ということになるが，これが意外に厄介であ る. 集合值確率変数の大数の法則の極限值は, 零 (空集合)にはなり得ないので，中心極限定理を記 述しようとするときに引き算が必要になるが, Minkowski 和にしても, 集合和にしてもその演算 が逆元となるような引き算がうまく定義出来ない． それでコンパクト凸集合全体を Banach 空間に埋 め込んで，そこで中心極限定理を得るのだが，そ れを元の集合族の空間にそのまま戻せない。それ で，上の埋め込みが等距離的だということに着目 して，距離だけで記述する形の定理を得るのだが， 
あまりきれいな形ではない，更に Gauss 分布も， 例えば全ての支持関数が Gauss 分布に従う，とい う定義にすると極く限られたものになってしまう。 これらの結果については $[5] と[17]$ が参考になる.

\section{5 マルチンゲール}

もうひとつの話題は，マルチンゲールである. 「確率 $1 / 2$ で勝負が決し，賭金と同額を得失する というゲームでは，今迄失なったのと同額の金額 を賭けるようにすれば，何時かは必ず勝つことが あるので，必ず元は取り戻せる.」という戦術がマ ルチンゲールの発祥とされており，この言葉は古 くから用いられていたという。これを，体系的な 理論として確立したのがDoob[3]で，今ではこの 理論は確率解析で久かせない存在になっている. これをランダム集合に持ち込んだのが[9]である。 これには，平均や条件付平均の定義と性質とか， 位相の導入とかのいろいろな準備が必要で，その 意味で彼等の功績は大きい。[18]はこれをファジ イ值確率変数に拡張したが，[12]と［13]ではそれ を整備して広いクラスに適用出来るようにした。 尚, 集合值マルチンゲールの収束定理の拡張と, 優または劣マルチンゲールの収束定理については [14]と [7]を参照されたい.

\section{6 その他の話題}

その他の話題だが, 重複対数の法則が, 5.3 節で 述べた Banach 空間への等距離埋め込みの形で, 得られている([5])。また，[1]は個別エルゴード 定理を，集合值とファジィ值の双方について得て いる。 [11]は論文の題名が興味を惹くが，内容は Malliavin calculus というより，Itô calculusを用 いて，ファジィ確率微分方程式を扱ったものであ る. 大偏差原理については，未だ手をつけられて いないようなので，今後の研究が待たれる，最後 に，ファジィ積分には触れないと書いたが，[19] はファジィ上の沉関数がファジィ積分で表される ための条件を与えていて興味をそそられる。

\section{7 今後の展望}

『今後の展望』ということだが，多くの分野が そうであるように確率ファジィ解析も, 数学的理 論と応用を結びつけるような，具体的な青写真は 見えて来ない，では将来が暗闇かというと，必ず しもそうでない．理論と応用の結びつきの過去の 例を見てみると，先ず理論で提起された言葉とそ の概念の応用への移入がある。これは，応用の方 へのアイデア提供という意味で馬鹿にならない。 次に，一見無関係に見える理論と応用の蓄積があ るが，その混沌とした中から応用の方にも真に有 用な理論や手段が生まれて来る。確率解析の例で 言えば, 中心極限定理が主役の統計的推定理論, 確率微分方程式の記述に欠かせないItô calculus, 制御理論における Kalmanフィル夕, 数理経済学 における Black-Scholes モデル等が挙げられよ う. 将来, 確率ファジィ解析にこれに匹敵する理 論や手法が生まれるという保障はないが，それで も希望は捨てたくない.今はその可能性を目指し て個々の理論を発展させて, 具体例を蓄積する時 期だろう。また，そもそもランダム集合の概念そ のものが, 数理経済学と数理統計学において, 互 いに独立に導入されたものであることから考えて， 現時点でも応用に役立つ道具が既にある筈なので， それを用いた仕事も期待されよう。

\section{6. あとがき}

本特集の記事で，前節までに紹介出来なかった ものが二つある．高橋渉氏の記事と吉田祐治氏-安田正実氏の記事である。前者は凸解析の立場か らファジィ集合の解析に迫るものであり, 今後の ランダムファジィの研究に欠かせない道具となる 期待が大きい，後者はファジィシステムにおける 意思決定についての総説だが，接近法は確率解析 で, 確率的なものを内包している。共に, 直接ラ ンダムファジィではないが，紛れもないファジィ 解析で, 確率解析とも極く近い関係にあるので, 本特集に加えたことを断っておく。 


\section{参 考 文 献}

[1]J. Bán, Ergodic theorems for random compact sets and fuzzy variables in Banach spaces, Fuzzy Sets and Syst., 44(1991), 71-82.

[2]G. Choquet, Theory of capacities, Ann. Inst. Fourier, 5(1955), 131-295.

[3]J. L. Doob, Stochastic Processes, Wiley, 1953.

[4]E. Giné and G. Hahn, Characterization and domain of attraction of $p$-stable random compact sets, Ann. Probability, 13(1985), 447-468.

[5]E. Giné, G. Hahn and J. Zinn, Limit theorems for random sets : an application of probability in Banach space results, in Probability in Banach Spaces IV, Lec. Note in Math. 990, 112-135, 1982.

[6]K. Handa, P. Kalukottege and Y. Ogura, A probabilistic interpretation of the degree of fuzziness, J. Appl. Probab., 31, (1994), 1034--1148.

[7]C. Hess, On the almost sure convergence of sequences of random sets: martingales and extensions, to appear in Jour. Pattern Recognizaton.

[8]F. Hiai, Convergence of conditional expectations and strong laws of large numbers for multivalued random variables, in Trans. Amer. Math. Soc. 291, (1985), 613-627.

[9]F. Hiai and H. Umegaki, Integrals, conditional expectations and martingales of multivalued functions, Jour. Multiva. Anal., 7 (1977), 149182.

[10]D. G. Kendall, Foundation of a theory of random sets, in Stochastic Geometry, eds. E. F. Harding and D. G. Kendall, Wiley, 1974.

[11]R. P. Leland, Fuzzy differential systems and Malliavin calculus, Fuzzy Sets and Syst., 70 (1995), 59-73.

[12]S. Li and Y. Ogura, Fuzzy random variables, conditional expectations and fuzzy valued martingales, J. Fuzzy Mathematics, 4(1996), 905927.

[13] S. Li and Y. Ogura, Convergence of set valued and fuzzy valued martingales, to appear in Fuzzy Sets Syst., 100 (1998).

[14] S. Li and Y. Ogura, Convergence of set valued sub- and super-martingales in the KuratowskiMosco sense, Ann. Probability 26(1998), 1384-
1402.

[15]G. Matheron, Random Sets and Integral Geometry, John Wiley and Sons, 1975.

[16]I. S. Molchanov, Limit Theorems for Unions of Random Closed Sets, Lec. Note in Math., 1561 (1993).

[17] M. L. Puri and D. A. Ralescu, The concept of normality for fuzzy random variables, $A n n$. Probab., 13 (1985), 1373-1379.

[18]M. L. Puri and D. A. Ralescu, Convergence theorem for fuzzy martingales, Jour. Math. Anal. Appl. 160(1991), 107-121.

[19]D. A. Ralescu and M. Sugeno, Fuzzy integral representation, Fuzzy Sets and Syst., 84(1996), 127-133.

[20] R. T. Rockafellar and R. J-B. Wets, Variational Analysis, Springer, 1998.

[21]H. E. Robbins, On the measure of a random set, Ann. Math. Statist. I : 14(1944), 70-74, II : 15(1945), 342-347.

\section{付 録}

研究集会『ファジイ解析とその周辺』の

講演者・講演題目一覧

神田 護(筑波大・数学系)：Random set の基礎をめ ぐって ( I) (II) (III)

高橋 渉 (東工大・情報理工学)：Shadows and Fixed

Point Theorems for Fuzzy Sets

井上洋(東京理大・経営)：Fuzzy Random Sets and

Convergence Results

本田亦扔い，岡崎悦明（九州工大・情報工）：ファジ 亿測度と意思決定

水本 雅晴 (大阪電通大・情報工)：最近のファジィ推 論法

石 岩 (九州東海大·工)，水本 雅晴 (大阪電通大・情報 工) : An Analysis on Neuro-Fuzzy Learning Algorithms

吉田祐治 (北九州大・経済), 安田 正實, 中神 潤一, 蔵野 正美(千葉大・理)：A fuzzy stopping problem with additive weighting function

吉田 祐治(北九州大・経済): On Optimal Stopping Problem of a Sequence of Fuzzy Random 
Variables

日合 文雄(茨城大・理)：Conditional Expectations for Normal Integrands

李寿梅(佐賀大・工学系)，小倉幸雄(佐賀大・理

I) : Convergence of Set Valued Sub- and Super-Martingales

（1998年9月30日 受付）
[問い合わせ先]

于 $840-8502$

佐賀市本庄町 1

佐賀大学理工学部数理科学科

小倉 幸雄

FAX ：0952-28-8501

E-mail : ogura@ms.saga-u.ac.jp

URL http://www.ms.saga-u.ac.jp/ ogura/

著 者 紹介

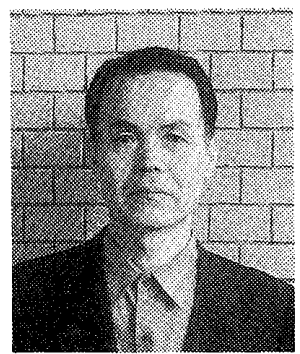

小倉 幸雄（おぐらゅきお）

佐賀大学数理科学科

1964年 京都大学理学部数学科卒. 同大 学院理学研究科修士課程修了. 理学博士. 九州大学工学部助手, 佐賀大学講師, 助教 授を経て現在传賀大学数理科学科 教授。 専門は確率解析学 